DOI: https://doi.org/10.32839/2304-5809/2019-3-67-72

UDC 81.25

Nechyporuk Viktoriia

National University of Ostroh Academy

\title{
CONCEPTS OF EQUIVALENCE IN THE MARTIN LUTHER TRANSLATION OF THE BIBLE AND ITS MODERN REVISION
}

Summary. In the article the concept of translation which is applied in the Martin Luther's Version of the Bible (in German) has been briefly considered; the aims of translators of the epoch of Reformation were defined. The translation methodologies of the newly published Luther Bible-2017 and its differences from the Martin Luther's original approach have been discussed. In the course of our research translations of 1545 and 2017 were compared; similarities and differences were found in the translation in the examples of different biblical texts. In particular, corrections in the new edition were considered and their appropriateness was justified. Conclusions were made on the significance of the translational techniques and their use in the revised translation; the target audience of the new translation was defined.

Keywords: the Luther Bible 2017, formal correspondence, dynamic equivalence, revision, concept of equivalence.

Нечипорук B.M.

Національний університет «Острозька академія»

\section{КОНЦЕПТИ ЕКВІВАЛЕНТНОСТІ В ПЕРЕКЛАДІ БІБЛІЇ МАРТІНА ЛЮТЕРА ТА ЙОГО СУЧАСНІЙ РЕДАКЦЇ̈}

\begin{abstract}
Анотація. У статті коротко розглянуто концепт перекладу, що був використаний у перекладі Біблії Мартіна Лютера (німецькою мовою) у шістнадцятому столітті, визначено цілі, які ставили перед собою перекладачі-колеги професора Лютера у часи Реформації. Коротко згадано подальші редакції перекладу Біблії Мартіна Лютера як спосіб збереження німецької народної, духовної та мовної спадщини. Обговорено методологію перекладу нещодавно опублікованої Біблії Лютера-2017 та ії̈ відмінності від оригінального підходу Мартіна Лютера. Введено числові дані, щоб показати відсоток змін, застосованих до нової редакції. В ході дослідження порівняно переклади 1545 та 2017 років та виявлено схожості та відмінності в розумінні поняття еквівалентності при перекладі на прикладі різних біблійних текстів. Особливе значення було надано обговоренню поглядів Мартіна Лютера на ефективний переклад і його ролі в принесенні концепту в німецьку наукову думку перед появою теорії функціональної еквівалентності Юджина Найди. Позиція Мартіна Лютера була проілюстрована численними прикладами емоційної мови, зокрема порівняннями та висловлюваннями, які використовував редрорматор. Крім того, розглянуто виправлення в новій редакції Біблії та обгрунтовано їхню доцільність. Виправлення класифіковано на такі, які були потрібні як через наявність нової наукової інформації, так і не ті, які були потрібні через розвиток та зміни в німецькій мові. Окрім того, дано оцінку повторному введенню застарілих конструкцій та формулювань у перегляд. висловлено погляди щодо їх зрозумілість у повсякденному житті. Оцінено важливість ролі синтаксису для розуміння текстів та перекладу синтаксичних структур. Зроблено висновки стосовно важливості технік перекладу та їх використання у редакції перекладу та визначено цільову аудиторію нового перекладу.
\end{abstract}

Ключові слова: Біблія Лютера-2017, формальна відповідність, динамічна еквівалентність, редакція, концепт еквівалентності.

Analysis of the recent research papers A and publications. The course of the research was guided by Eugene Nida and Charles Taber's groundbreaking works on principles applied during Bible translation. Determining Luther's methods of translation we made use of Philip Shaff's works [14]. Detailed explanation of style in Luther's translation was found in Birgit Stolt's body of research [15]. Martin Karrer, Ursula Kocher, Christoph Melchior, and Christoph Kaehler [7], who had worked on the translation itself, gave a deep insight into the process of the revision of the Bible alongside with aims of translators and editors.

The purpose of the study is to discover if the Luther Bible-2017 how the basic methodological approaches of the renewed Luther version (2017) correlate with the principles of the dynamic equivalence, and which innovations have been introduced in this version.

The main material. Many theorists of translation agree that the 20th century has brought forth development of scientific thought which resulted in a multitude of cutting-edge theories in the realm of translation studies. One of them was devised in the 1960s by Secretary for Translations in the American Bible Society Eugene Nida and his colleague Charles Taber with the goal of helping missionaries to render the Word of God into languages of the unreached people groups. The kernel of the theory lies in two contrasting ideas about equivalence in translation. While formal correspondence is described as orientation in translation towards the original text (its syntax, expressive means etc.) dynamic equivalence is aimed at causing the same emotional reaction to the translation that readers of the original have. This means that a translator ought to consider the culture of the language of translation, the broad context of the source text and the target audience. Within the course of several decades the theory proved its right to exist since from that time many translators have successfully ap- 
plied ideas of dynamic (functional) equivalence in practice $[12 ; 13]$.

Even though Eugene Nida and Charles Taber gave special prominence to 'sense-to-sense translation' and devised a well-developed theory with emphasis on dynamic equivalence, they were not the first to put the aforementioned into practice. In fact, at the dawn of the European Reformation a celebrated theologian and author of the history-making translation of the Bible into the German language Martin Luther expressed similar ideas in simpler words. After the New Testament was published, the reformer was repeatedly criticized by papists for not adhering to the Latin text during his work on the translation. In this case Luther's primary justification was that he oriented towards the sources of the German language, towards its syntax and phraseology. Moreover, addressing catholic claims he wrote in his 'Open Letter on Translating' the following legendary words: '... we must consult the mother at home, children in the street, and the ordinary man in the marketplace, watch them mouth their words, and translate accordingly. That way they'll understand, and see that they're being spoken to in German'. Thus, the theologian generalized the above mentioned theory [9, p. 17].

Speaking about the long-lived tradition of regular revisions of the Luther Bible, the reformer himself established it soon after publication of the whole Bible in 1536. The theologian attached great importance to careful examination and improvement of the work done with emphasis on detailed investigation of every single word. Alongside with this he tried to follow his concept of style. First of all, for Luther appropriate style meant emotional thinking, that is to say he tried to feel the text with this heart. Such standpoint reflected itself in Luther's attitude to certain sacred parts of the Holy Scripture. To site an instance, he called the Epistle to the Galatians 'my Katie von Bora'. Additionally, he rendered some biblical words not with the help of ideally corresponding terms nut rather with those words that could deeply affect the listener. One example could be that in Genesis (chapter 44, verses 31 and 34) he replaced technically ideal 'Unglück' with 'Jammer', which better reflects sorrow [15, p. 382]. To the most known revisions belongs Luther's formulation and later alteration of 1 Corinthians 13, 8. One of the earliest renderings of the verse sounded 'Die Liebe wird nicht müde' and in the 1546 version was changed to 'Die Liebe höret nimmer auf' [14].

Only on comparatively rare occasions Luther retreats from his idea 'let the letter go,' and translates 'word for word' if, as an example, he thought that the Hebrew or Greek original was more appropriate or too ambiguous to be interpreted in one way. He and his co-translators altogether prepared five different editions, successfully combining both strategies of translation under the condition that words served the sense, but not vice versa [14, p. 194]. With aforementioned ideas in mind Luther and his co-workers amended this splendid book the whole decade. The last revision completed during his life appeared in 1545 .

After Luther's decease his comrades undertook a task of revision and translation passing the tra- dition down to new generations. In a few centuries a pressing need for new editions arose even more because since Luther's time many changes had happened to the language of Germans. In order to preserve the church heritage and adapt it to modern needs revisions of $1912,1975,1984$ and others were published, the last successor being the Luther Bible 2017.

Prior to start of the work in 2010 the Council of the Evangelical Lutheran Church decided that an edition of the Luther Bible ought to appear before the 500th anniversary of Reformation. It had to be a revision of the 1984 revision. For this task 70 translators were employed. They aimed at implementation of certain criteria during their work, the most important being loyalty to the original scriptures and to Luther's language. Other their goals are precision and comprehensibility of translation together with amendment of additional information (maps, explanations in footnotes) in accordance with the latest research data [3]. Moreover, that translation meant to be all-inclusive, that is to say it had to use both feminine and masculine forms (if both sexes were addressed in scripts) and to satisfy all Christian denominations [7].

Two firstly mentioned criteria deserve particular attention and explanation. During the work translators armed themselves with original Hebrew and Old Greek Texts, namely OT Biblia Hebraica, the Septuagint, the 27th and 28th editions of NT Nestle-Aland, Qumran scrolls and some other sources. At the same time being informed that language of the Luther's Bible is no longer modern in the 21st century, they decided to hold on strongly to it and retain it in the new edition. Altogether, historians, philologists and theologians who worked on the text tried to return to Luther's German through reformulation of his translation (so called 'Rückrevision'). They even replaced many amendments that were introduced in the 20th century if the Luther's language was still understood [10, p. 3-5].

The result of their ambitions was a philological translation with strong influence of 'the sound of Martin Luther' [1.]. According to statistics, up to 16000 verses of the 1984 revision were altered in the 2017 revision. That constitutes $44 \%$ of the whole Bible. Furthermore, nearly $10 \%$ of words were changed. However, alterations were mostly applied to the apocryphal books, so the overall change of words in the Old and the New Testament reaches only 5\% [4]. Of course, this data witnesses of the grand scale of ambitions of translators and their striving for greater efficiency.

As it was aforementioned, in some cases translators corrected Luther's original version if new scientific evidence demanded a change. The text of Philippians 4, 7 can be instanced here. 'Und der Friede Gottes, der höher ist als alle Vernun$\mathrm{ft}$, wird eure Herzen und Sinne in Christus Jesus bewahren' (die Lutherbibel-2017) [2]. ('And the peace of God, which transcends all understanding, will guard your hearts and your minds in Christ Jesus' according to the New International Version) [16]. Even though Erasmus of Rotterdam proposed the future tense for this verse as it was used in the original text, Martin Luther followed 
here grammar of the Latin Vulgate with the present subjunctive: 'Und der Friede Gottes, welcher höher ist denn alle Vernunft, bewahre eure Herzen und Sinne in Christo Jesu!' [8]. Discovered later Greek texts confirmed Erasmus' suggestion, and necessary corrections were applied to the new version. The usage of the present subjunctive did not prevent people from understanding the meaning of the passage, still the correction made in the Luther Bible 2017 is methodologically correct.

One further alteration was made in the Gospel according to Matthew 8, 24. Luther's 'großes Ungestüm im Meer' was replaced with 'großes Beben im Meer', which renders the meaning of the natural phenomenon accurately with the help of a modern and familiar word $[2 ; 8]$. Another change in the same Gospel is applied to verse 19 of the 28 th chapter. From 1526 the text sounded 'Darum gehet hin und lehret alle Völker und taufet sie...' [8]. From 1956 the text sounded 'Darum gehet hin und machet zu Jüngern alle Völker. Tauft Sie...' In the 2017 revision translators come back to Luther's formulation: 'Darum gehet hin und lehret alle Völker: Taufet sie...' [2].

Nevertheless, on close examination contradictory corrections appear. The 1984 edition of the Luther Bible rendered Luke 1, 50 ('Mary's song') as following: 'Und seine Barmherzigkeit währt von Geschlecht zu Geschlecht bei denen, die ihn fürchten' [10]. In the new version theologians and translators reached a decision to introduce the readers to Luther's 'für und für' instead for 'von Geschlecht zu Geschlecht'. While, of course, older translation might sound poetically, not every reader is familiar with the meaning of the idiom.

There are many other examples of preferences for obsolete words and formulations in the Luther Bible 2017. The book of Genesis practically begins with them. The third verse of the first chapter is practically identical to Luther's revision of 1545 . 'Und Gott sprach: Es werde Licht! Und es ward Licht'. The imperative form sounds rather official and impartial, but questions arise to the verb 'ward'. Defined by Duden dictionary, this is either a poetic or an old-fashioned form of 'wurde' [5]. Certainly, in Luther's times the word was commonly used, but due to changes in the language it became obsolete. This leads us to conclusion that revisers intentionally copied the word from the source text into the revision thus leaving a modern reader confused.

Shifting the focus to syntax in the Luther Bible 2017, one can notice that here this version follows other formal-correspondence translations. The sentence structure in the Hebrew language is paratactic. That means that grammatical coordination dominates in sentences $[11, \mathrm{p} .2]$. This was partially caused by the fact that in the past the Hebrew did not have a system of punctuation; coordinating conjunctions performed its role. Formal-equivalence translations follow the syntax of the source language, and this is particularly evident in the example of conjunctions. Continuing the exploration of the first chapter of the Bible, it is easy to notice abundance of 'und' (German conjunction for 'and') in the beginning of almost every sentence, although translators could use other means to make translation more dynam- ic and diverting. '9 Und es geschah so. 10 Und Gott nannte das Trockene Erde...' [8]. This verse from the Book of Genesis from the Luther's late edition is word-for-word repeated in the new version. This is just one instance of appearance of the same conjunction twice in a raw, although every chapter of the whole Bible is filled with them. At times translators apply this conjunction for clarity to some places of the passages where Luther omitted them, or sometimes they do it vice versa if another word matches the context better. One example of this can be the following verse:

Ich schaute das Land an, siehe, das war wüst und öde, und den Himmel, und er war finster. (From the Luther Bible 1545 [8]).

Ich sah das Land, und siehe, es war wüst und leer, sah zum Himmel, und er war finster (From the Luther Bible 2017 [2]).

In the second verse one can notice that the verb 'sah' is repeated in the same sentence twice (instead of Luther's preference for the conjunction 'und') with the result that the reader sees the connection between small parts of the Holy Scripture. However, in the revision translators added the aforementioned conjunction to the word 'siehe' ('und siehe, es war wüst und leer' [2]) so as to make logical connection between actions visible.

All in all, on closer examination a mass of positive changes, which were needed in the view of scientific advance in knowledge, appears. These modernisations, however, do not mean incorporation of the spoken language of German population. In fact, translators assert that that the target group of their work were people familiar with the liturgy of the Lutheran church, the Luther's Bible and its sophisticated style. They admit that people with no Christian background ought to start their road to God with other versions, the 'Gute Nachticht Bibel', the 'Basis Bibel', to name just some [6].

Conclusions. Taking into account everything aforementioned one can reach a conclusion that the latest revision of the Luther Bible in general follows Martin Luther's criteria for a good translation, taking into account, however, only one target group, namely people who are familiar with the church liturgy and lifestyle. Thereto, the process of reading might at times be a complex yet a feasible task. This conviction originates from the idea that a dynamic translation is not fully possible if authors of a revision set a goal to come to Luther's word order and original sound (in other words, to the 16th century) as close as the language still permits and, as a result, attach importance only to direct translation techniques which signify preference for formal correspondence.

Although some other German translations of the Bible have overtaken the Luther Bible due to their modernity, it is significant to mention its importance for the Evangelical Lutheran Church and for preservation of the historical heritage of the Reformation for the German nation and the whole world. Considering the fact that both translation and revision of the Holy Scripture are complex and demanding tasks the suggestion would be to continue to compare the impact that every translation makes on its readers with the criteria for a 'sense-to-sense' translation. 


\section{References:}

1. Deutsche Bibelübersetzungen im Vergleich. Available at: https://www.die-bibel.de/bibeln/bibelkenntnis/wissenbibeluebersetzung/deutsche-bibeluebersetzungen-im-vergleich/ (accessed 30 January 2019).

2. Die Lutherbibel 2017. Available at: https://www.die-bibel.de/bibeln/online-bibeln/lutherbibel-2017/bibeltext/ (accessed 30 January 2019).

3. Die revidierte Lutherbibel 2017. Available at: https://www.die-bibel.de/bibeln/online-bibeln/lutherbibel-2017/ informationen-zur-bibeluebersetzung/ (accessed 5 February 2019).

4. Die Revision der Lutherbibel. Available at: https://www.die-bibel.de/ueber-uns/unsere-uebersetzungen/ lutherbibel-2017/wasistneu/revision/ (accessed 31 January 2019).

5. Dudenverlag. Duden. Deutsches Universalwörterbuch (2001). 4., neu bearb. u. erw. Mannheim u. a.: Dudenverlag.

6. Eduard Kopp. Das Interview mit Die Bibel neu gelesen: Der Hirsch lechzt nicht mehr. Interview zur Revision der Lutherbibel. Available at: https://www.ekd.de/revision-lutherbibel-christoph-kaehler-12544.htm (accessed 25 January 2019).

7. Ursula Kocher, Martin Karrer. Making old things new - the revision of Luther's Bible Ausgabe. Available at: https://www.buw-output.de/en/archive/ausgabe13/making-old-things-new-the-revision-of-luthers-bible/ (accessed 29 January 2019).

8. Luther Bibel 1545. Available at: https://www.biblegateway.com/versions/Luther-Bibel-1545-LUTH1545/\#booklist (accessed 12 February 2019).

9. Luther M. (2017). Der Sendbrief von Dolmetschen. Oxford : Taylor Institution Library, p. 92.

10. Lutherbibel 1984. Available at: https://www.die-bibel.de/bibeln/online-bibeln/lutherbibel-1984/bibeltext/bibel/ text/lesen/stelle/52/10001/19999/ (accessed 12 February 2019).

11. Meek T.J. The Syntax of the Sentence in Hebrew (1945). Journal of Biblical Literature, vol. 64, no. 1, pp. 1-13.

12. Eugene A. Nida, Charles E. Taber (1982). The Theory and Practice of Translation. Leiden : Brill, p. 218.

13. Nida, Eugene A. (1964). Toward a Science of Translating. With Special Reference to Principles and Procedures Involved in Bible Translating. Leiden : Brill, p. 331.

14. Philip Shaff (2002). History of the Christian Church, Volume VII. Modern Christianity. The German Reformation. Grand Rapids, MI : Christian Classics Ethereal Library Publisher, p. 441.

15. Stolt B. (2014). Luther's Translation of the Bible. LUTHERAN QUARTERLY. vol. XXVIII, pp. 373-400.

16. International Bible Society (2011). The Holy Bible. New International Version. Colorado Springs, p. 882. 